Artigo Original

\title{
Comparative analysis of water and energy balance between conventional system and agroforestry system of production
}

\author{
Análise comparativa do balanço hídrico e energético entre sistema convencional e sistema \\ agroflorestal de produção.
Gabriela Leite Neves', Tainá Thomassim Guimarães", Allita Rezende dos Santos"', Frederico Fabio Mauad'v

\section{Abstract}

The structure of an agroforestry system differs from conventional agriculture and forestry, because it has an environmental function, improving the system's productivity due to more efficient use of natural resources (space, soil, water, light and nutrients) and complementary relationships between the components. It is the changes in the microclimate of agroforestry systems that directly affect the water and energy balance of these environments, thus, this paper had as main objective to perform a comparative analysis of the water and energy balance of two models of soil cover for the Ribeirão do Feijão (Feijão creek) basin, located in the municipalities of Itirapina and São Carlos/ State of São Paulo, a conventional agriculture situation (where the soil is covered by monoculture - oranges) and another one with agriculture in the model of Agroforestry Systems. The water balance extract was obtained using the Thornthwaite and Mather methodology (1955) and the balance of radiation and the energy balance for the systems under analysis were estimated. The results suggest that the agroforestry system can help conserve resources used in agriculture. Nevertheless, the importance of more studies in the area is emphasized to obtain an understanding of the "soil-water-energy-plant" relationship.

Keywords: Agroforestry system; Water balance; Energy balance

\section{Resumo}

A estrutura de um sistema agroflorestal diverge da agricultura e silvicultura convencionais, pois apresenta uma função ambiental, melhorando a produtividade do sistema devido ao uso mais eficiente dos recursos naturais (espaço, solo, água, luz e nutrientes) e às relações complementares entre os componentes. São as alterações no microclima dos sistemas agroflorestais que afetam diretamente o balanço hídrico e energético desses ambientes, assim, este trabalho teve como objetivo principal realizar uma análise comparativa dos balanços hídricos e energéticos de dois modelos de coberturas do solo para a bacia do Ribeirão do Feijão, localizada nos municípios de Itirapina e São Carlos/ SP, sendo uma situação de agricultura convencional (onde o solo é coberto por monocultura de laranja) e outra com agricultura no modelo de Sistema Agroflorestal. Obteve-se o extrato do balanço hídrico por meio da metodologia de Thornthwaite e Mather (1955) e estimou-se o saldo de radiação e o balanço energético para os sistemas em análise. Os resultados obtidos sugerem que o sistema agroflorestal pode auxiliar na conservação dos recursos utilizados em uma agricultura. No entanto, ressalta-se a importância de mais estudos na área para que se possa ter uma compreensão da relação "solo-água-energia-planta".

Palavras-chave: Sistema agroflorestal; Balanço hídrico; Balanço de energia

\footnotetext{
II,II Student of the Postgraduate Programme in Environmental Engineering Sciences. São Carlos Engineering School (EESC), University of São Paulo (USP), São Carlos, SP, Brazil - gabriela.leiteneves@usp.br; tainathomg@usp.br; allita.santos@gmail.com

Iv Professor of the Postgraduate Programme in Environmental Engineering Sciences. São Carlos Engineering School (EESC), University of São Paulo (USP), São Carlos, SP, Brazil - mauadffm@sc.usp.br
} 


\section{Introduction}

The increasing demand for natural resources and their consequent loss of quality and quantity indicates the need to develop alternatives aiming to minimize impacts. In the case of agricultural ecosystems, conventional farming practices have led to the degradation of soil and water resources, loss of biodiversity and destruction of ecosystems over time, leading to imbalances in water balance and temperature.

Understanding that the components of a system interact with each other and that the system is dynamic makes it easier to seek solutions to management problems for the best production and sustainability. Agroforestry practices can be strategic to improve natural resource management, contributing to solving problems in the use of these resources due to the biological and socioeconomic functions they can fulfill in the system (ENGEL, 1999; LUEDELING et al., 2016).

Nair (1989) defined agroforestry systems as land use and technologies systems in which perennial woody species are used in the same management unit as agricultural crops or animals in some spatial arrangement and temporal sequence. The agroforestry system has good ecological, social and economic benefits compared to traditional farming. These agroforestry systems not only increase farmers' incomes and contribute to food security, but also play a role in increasing plant cover and cushioning extreme weather events (JIANBO, 2006).

According to Engel (1999), the main objective of agroforestry systems is to optimize land and radiant energy use, reconciling forest production with food production, conserving soil and water, and reducing pressure for land use for agricultural production. Also according to the author, the presence of trees in these systems brings direct and indirect benefits, such as erosion control and maintenance of soil fertility, increase of biodiversity, diversification of production, lengthening the management cycle of an area and improvement in water quality. Lu et al. (2015) indicate that studies in several locations in China have shown that agroforestry systems usually produce better ecological and economic benefits than monoculture.

The agroforestry system is a complex and living system that integrates the trees and results in changes in the microclimate which, in turn, influence the growth of all system components (SINGH et al., 2012). Young (1991) points out that the main interactions of agroforestry systems with the environment refer to microclimate (solar radiation, air humidity, temperature, and wind) and soil (erosion and fertility).

The potential of agroforestry practices has also been demonstrated in terms of carbon sequestration in wood and soil and its impact on emissions of other greenhouse gases, either positively or negatively. In this way adopting these systems helps farmers to adapt to climate change through the risk mitigating effects of additional agricultural products derived from trees, positive microclimate effects through shading and increased agricultural productivity through tighter nutrient and water cycles (LUEDELING et al., 2016).
In relation to microclimatic changes in the environment, it is observed that the planting of trees decreases the average radiation incident on cultivated plants. Although these changes can be considered a disadvantage in relation to plants (if they have characteristics that require high incident light), the main advantage is related to the regulation of the microclimate by reducing the temperature in the environment, higher humidity, lower rates of evapotranspiration and higher levels of soil moisture. All these factors will change as a function of tree development and tree management practices. The spacing scheme chosen for the trees will also be a factor in determining how quickly changes take place (SINGH et al., 2012).

Competition for light is one of the main interactions between trees and plantations. Trees reduce the amount of sunlight that reaches soil and crops through shading. Light capture is influenced by environmental and plant factors such as tree leaf area, leaf phenology, crown structure, and crown management. Unless trees have no leaves during the growing season or are pruned, competition can be substantial (LUEDELING et al., 2016).

A particular challenge is quantitatively estimating the combined effects of microclimate modification and shading on sub-forest crop growth. Although the reduction of photosynthetically active radiation through shading generally has negative implications for crop growth, higher air humidity and reduced temperature have positive effects in hot climates (LUEDELING et al., 2016).

Agroforestry practices can further improve the efficiency of water use by reducing non-productive components of the water balance, such as surface runoff, soil evaporation or drainage (LUEDELING et al., 2016). According to Monteith, Ong, and Corlett (1991), when plant growth is not affected by water or nutritional deficit, productivity is basically controlled by the amount of radiant energy available to the crop. Singh et al. (2012) also point out that lower temperatures under the canopy can reduce stress due to water deficit and increase the biomass of plants adapted to shade if competition for light or water does not exceed the benefits of temperature reduction in the system.

In this way, the implantation of non-conventional agriculture systems, such as agroforestry systems, influences the water balance of the region, as they impact microclimate reducing the temperature and, consequently, interfering in the evapotranspiration of the crops there.

Furthermore, changes in radiation and wind speed caused by the introduction of trees have very significant effects on the energy balance of the plant. According to Singh et al. (2012), the plant must lose the same amount of energy it absorbs if it is to remain at a constant temperature. Although a certain amount of energy is stored as chemical bonding energy, photosynthesis and physical storage of heat, energy is lost mainly through evaporation and convection.

It is these changes in the microclimate that directly affect the water and energy balance of environments that have adopted agroforestry systems. In this sense, this research had as aim to compare the water and energy 
balance of a conventional agricultural system and an agroforestry system in the Feijão creek Hydrographic Basin, located in the municipalities of Itirapina and São Carlos, State of São Paulo, Brazil.

\section{Materials and methods}

\subsection{Study area}

The Feijão creek Hydrographic Basin is part of the Paraná basin and the Tietê-Jacaré River sub-basin, located in the upper part of the Jacaré-Guaçu River (important tributary of the right bank of the Tietê River) (CERMINARO, 2015). It is located in the east-central region of the State of São Paulo (Figure 1), between the parallels $47^{\circ} 93^{\prime}-47^{\circ} 76^{\prime} \mathrm{W}$ and $22^{\circ} 16^{\prime}-22^{\circ} 07^{\prime} \mathrm{S}$.

The Feijão creek Hydrographic Basin are located high in the Serra do Cuscuzeiro mountain range in Analândia, and its main watercourse runs through the municipalities of São Carlos, Analândia and Itirapina. The basin accounts for $40 \%$ of the water supply in São Carlos (CERMINARO; OLIVEIRA, 2015). The estimated population of São Carlos for 2016 was over 240 thousand inhabitants in a territorial unit of more than 1 million $\mathrm{km}^{2}$ (IBGE, 2017). This region is part of the Corumbataí Environmental Protection Area (APA) and comprises the Protection Area and Recovery of Feijão creek Headwaters (APREM), established by Law No. 13,944, of 2006 (CERMINARO, 2015).

The climate of the study region according to the Koeppen classification is of the Cwa type, characterized as tropical climate at altitude, rainy in the summer and dry in the winter, average temperature in the hottest month exceeding $22^{\circ} \mathrm{C}$ (CEPAGRI, 2017). The mean annual temperature is $26.9^{\circ} \mathrm{C}$ (maximum) and $16.2^{\circ} \mathrm{C}$ (minimum), relative humidity is $76 \%$ in summer and $54 \%$ in winter (CERMINARO, 2015), and the mean annual rainfall exceeds 1,400 mm (NISHIYAMA, 1991).

The soil types found in the Feijão creek region are mainly Deep Quartzose Sands and Yellow Red Latosol, occupying more than $60 \%$ of the area of the basin, and in smaller plots Litolic, Purple Latosol, Hydromorphic, Red Yellow Podzolic, Structured Purple Latosol and Dark Red Latosol soils (CUNHA, 2012).

The soil cover (Table 1) demonstrates the types of use and occupation in the basin area of Feijão creek. The vegetation on the river banks, sugarcane, corn, and orange plantations, as well as forest species such as eucalyptus, buffaloes, farms, poor communities, industrial hubs, recreational use and farms (CERMINARO; OLIVEIRA, 2015).

Considering the soil cover in the Feijão creek basin, and in order to evaluate the use of natural resources in two different systems, it was decided to conduct the water and energy balance of an area of $1 \mathrm{~m} 2$ of orange monoculture (coverage of $13.8 \%$ of the basin) to later compare its results with the balances of the same area with a model of an Agroforestry Systems. The agroforestry systems characteristics will be presented in the following topic.

To determine the water and energy balances, daily data were obtained for mean air temperature (minimum and maximum), global solar radiation $(\mathrm{Qg})$, relative humidity and insolation of the Embrapa Southeast Livestock Station and also the conventional National Meteorological Institute - INMET station.

Figure 1 - Location of Feijão creek Basin

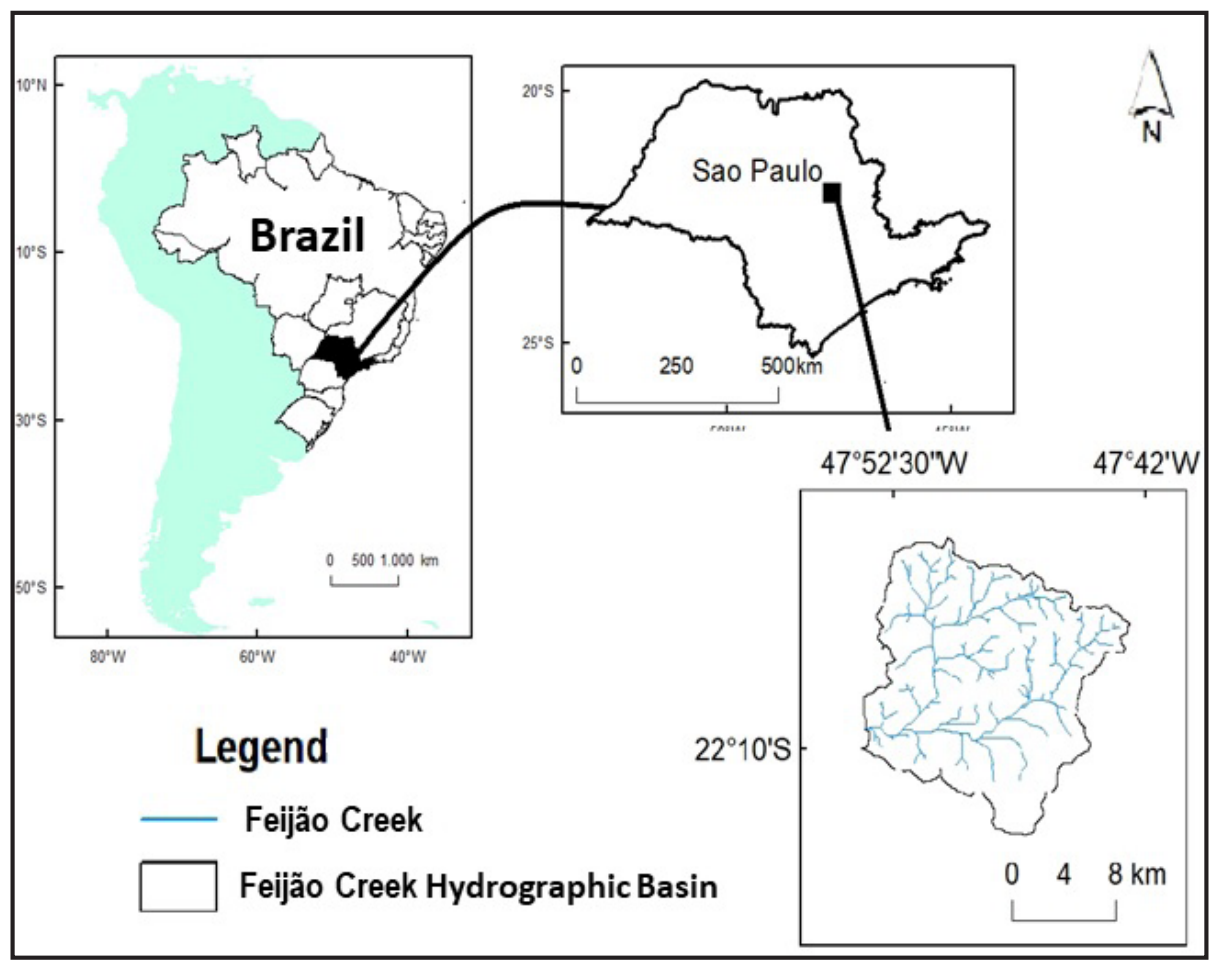

Source: The authors. Source of the data: IBGE (2017) 
Table 1 - Percentage occupied by the soil cover in the Feijão creek basin.

\begin{tabular}{lcc}
\hline \multicolumn{1}{c}{ Soil cover } & Area (ha) & Area (\%) \\
\hline Pasture & $8,584.5$ & 38.52 \\
Oranges & $3,085.1$ & 13.8 \\
Exposed soil & $2,861.3$ & 12.8 \\
Riparian/Hill Forest & $2,357.65$ & 10.6 \\
Reforestation & $2,280.6$ & 10.25 \\
"Cerradão" & $1,293.45$ & 5.8 \\
Urban & $1,083.65$ & 4.85 \\
Sugar cane & 680.65 & 3.33 \\
Water & 13.1 & 0.05 \\
\hline Source: Adapted from Cunha(2012) & &
\end{tabular}

\subsection{Agroforestry System Proposal}

Prior to the development of an agroforestry project, detailed technical specifications should be established and a study of species appropriate to local conditions carried out. In addition, factors such as local climate (temperature, precipitation, radiation), topography, soil and hydrological conditions should be considered (LU et al., 2015).

According to Armando et al. (2012), in order to have a production system with different crops, it is necessary to consider the needs of each plant, such as light, size, type of root system, type of climate and soil required, as well as the effect of each species on the growth and production of the other components of the system over time and within the space available (ARMANDO et al, 2012).

This planning enables a spatial distribution of the species that is usually presented through a design of an Agroforestry System. According to Nardele and Conde (2008), the design is extremely important because it illustrates the arrangement of seedlings and seeds on the ground, taking into consideration the desired spacing between the trees.

Considering that the paper proposes to compare the water and energy balance of an agroforestry system with a conventional area of agriculture, it was decided to consider orange monoculture in the system, in order to maintain the agricultural production characteristic of the region.

It is proposed that, together with the orange crop, the agroforestry system be composed of Eucalyptus (perennial tree) and banana. In this system, the main focus of production would be the orange itself, with the eucalyptus and banana used to help in the production of organic matter for the soil while also being of commercial value to producers.

The choice of these crops is justified by the fact that they are already used in agroforestry systems, obtaining good results in terms of their productivity and their arrangements, so that one species does not harm the development of the other.

In this way, the species used and the spacings to be adopted in the agroforestry system are shown in Table 2 , as is the design of the model presented in Figure 2.
Table 2 - Agroforestry system species and spacing

\begin{tabular}{lc}
\hline \multicolumn{1}{c}{ Species } & Spacing (line $\times$ column) \\
\hline Eucalyptus & $12 \mathrm{~m} \times 6 \mathrm{~m}$ \\
Orange & $12 \mathrm{~m} \times 3 \mathrm{~m}$ \\
Banana & $6 \mathrm{~m} \times 3 \mathrm{~m}$ \\
\hline
\end{tabular}

Figure 2 - Design of agroforestry system model adopted

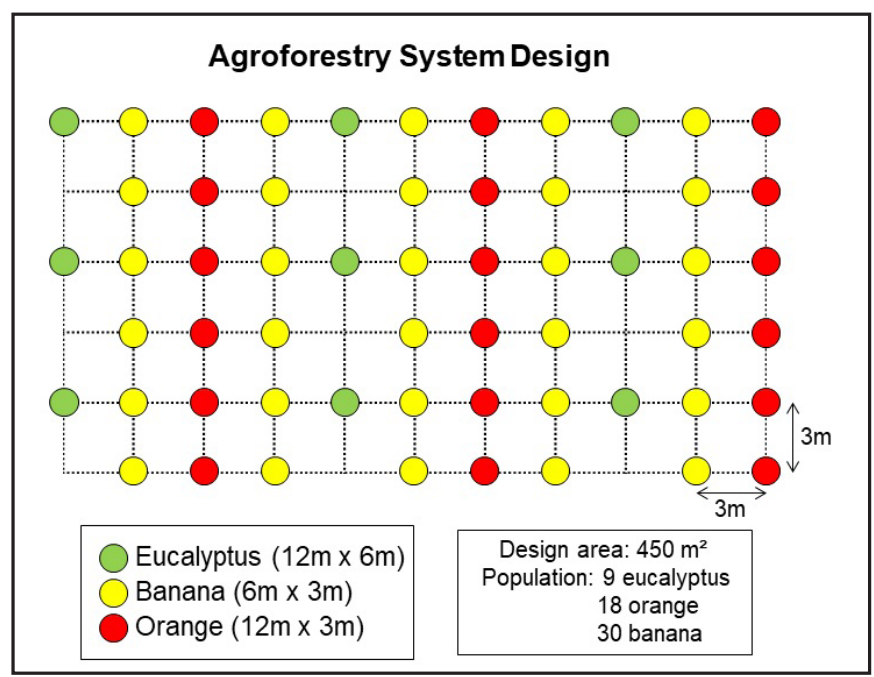

Source: The authors. Source of the data: IBGE (2017)

\subsection{Calculation of evapotranspiration}

In order to analyze the amount of water available and then apply the water balance, it is necessary to first estimate evapotranspiration (ET) corresponding to water loss to the atmosphere through evaporation from the soil and wet vegetation and transpiration of plants, thus representing the plants' water requirements, having a direct influence on water availability (PEREIRA; ANGELOCCI; SENTELHAS, 2007).

In ideal conditions of water, temperature and other local meteorological variables, the water lost by evaporation and transpiration of an extensive underbrush is defined as potential evapotranspiration (ETP). However, the water used by this surface, with or without water restriction, is represented by real evapotranspiration (ETR).

In this study, ETP was estimated using the Thornthwaite Method (1948), which considers as input data the average temperature and the geographical coordinates of the site.

Considering the shading by eucalyptus and the reduction of the microclimate in the agroforestry system, a reduction of $7 \%$ in the average air temperature was projected to estimate the evapotranspiration of this system, as found in other studies (KARVATTE JUNIOR, 2014; KARVATTE JUNIOR et al., 2016).

In view of the aim of calculating the water balance for crops, crop evapotranspiration (ETc) was estimated to represent the amount of water used by a crop, at any stage of its development, when there is no water restriction. The ETc was obtained based on ETP through the ratio:

$E T C=K c E T P$ 
When $\mathrm{Kc}$ is the crop coefficient that varies with the phenological phases, and also between species and varieties (cultivars). Thus, the following Kc were considered for each crop, according to Bulletin 56 of the Food and Agriculture Organization (FAO) of the United Nations:

Table 3 - Kc of the final phase for the crops

\begin{tabular}{lc}
\hline \multicolumn{1}{c}{ Crop } & Kc (final phase) \\
\hline Eucalyptus & 1.00 \\
Banana & 1.00 \\
Orange & 0.65 \\
\hline
\end{tabular}

Source: FAO Bulletin 56

In order to obtain the common ETc representing the three crops in the agroforestry system, the area of $1 \mathrm{~m}^{2}$ was considered. Thus, the estimated ETc for one plant by the population in one hectare was multiplied according to the spacing of the orange in the monoculture and of the eucalyptus, banana and orange in the agroforestry system, as shown in figure 3 , and the ETc was later divided by $1 \mathrm{~m}^{2}$.

After obtaining the evapotranspiration per plant, the values of ETc per plants in one hectare (population of one ha) was added, obtaining the ETc of the area.

\subsection{Water balance}

The water balance $(\mathrm{BH})$ was estimated using the methodology of Thornthwaite and Mather (1955), in order to determine the water availability in the soils of the orange monoculture and the agroforestry system suggested in this paper.

The water input and output components of the soil system were accounted for based on the water balance estimation. The rainfall precipitation (PREC) corresponds to the main input component of the system, together with dew $(\mathrm{O})$, surface runoff $(\mathrm{Ri})$, sub-surface runoff (DLi) and capillary ascent (AC). Evapotranspiration is the main output component along with surface runoff (Ro), sub-surface runoff (DLo) and deep drainage (DP). The values of dew and capillary ascent are negligible, since they occur only in very dry periods and in arid regions. In homogeneous areas, the horizontal water flows ( $\mathrm{Ri}, \mathrm{Ro}$, DLi and DLo) are compensated and, therefore, annulled (PEREIRA; ANGELOCCI; SENTELHAS, 2007).

Therefore, the water balance can be represented by the following equation:

$$
\triangle A R M=P R E C-E T-D P
$$

In order to determine the amount of available soil water in both systems (monoculture and agroforestry) for the year 2016, the sequential water balance was found, which characterizes and provides the seasonal variation of $\mathrm{BH}$ (deficiencies and surplus) conditions over the period in question.

As the objective is to obtain the water balance for the crops, previous ETc was obtained for the systems, as detailed in item 2.3. Thus, the water balance was estimated for an area of $1 \mathrm{~m}^{2}$ in order to compare the monoculture system with an agroforestry system, where three crops are considered.

The available water capacity (CAD) was selected according to the type of crop, so, for the water balance of the orange monoculture, $\mathrm{CAD}=100 \mathrm{~mm}$ was adopted and $\mathrm{CAD}=150 \mathrm{~mm}$ was used for the agroforestry system.

Based on the PREC, ETc and CAD data, the parameters of actual evapotranspiration (ETR), soil water storage (ARM), accumulated negative (NAc) of soil water alteration $(\mathrm{ALT})$, soil water deficit $(\mathrm{DEF})$ and water surplus (EXC) were calculated.

\subsection{Radiation Balance and Energy Balance}

In order to compare the balance of available energy in the orange monoculture system and in the agroforestry system, the radiation balance and the respective energy balance were found.

The energy available for biological and/or physical processes on a land surface depends directly on the distribution of solar radiation, which can be accounted for by means of the radiation balance that is characteristic of a surface that may be covered by vegetation or by any material, soil without cover, a liquid surface, etc. This radiation balance is composed by short wave (BOC) and long wave (BOL) balance, resulting in the balance of $R n$ or liquid radiation. It can be represented by:

$$
R n=B O C+B O L
$$

The short-wave radiation (BOC) is established by the absorption, diffusion and reflection processes that occur when radiation interacts with the atmosphere and with the surface. The part of the solar radiation that arrives at the top of the atmosphere is known as Q0, and approximately $52 \%$ of that radiation reaches the surface $(\mathrm{Qg})$ and the rest is reflected. A fraction (4\%) of Q0 is reflected by the surface representing $r Q g$, when $r$ is the surface reflection coefficient, and $48 \%$ is absorbed by the soil (PEREIRA; ANGELOCCI; SENTELHAS, 2007).

Long-wave balance (BOL) is the accounting for thermal energy input and output from the earth's surface and atmospheric components. The energy input corresponds to the flux of radiant energy emitted by the atmosphere towards the surface, also known as Qa or Qatm. The energy output in the system corresponds to the flux of radiant energy emitted by the atmosphere towards the surface, known as Qs or Q sup (PEREIRA; ANGELOCCI; SENTELHAS, 2007).

Therefore, daily data on mean air temperature (minimum and maximum), global solar radiation $(\mathrm{Qg})$, relative humidity and insolation were used. Based on these data, BOC and BOL were calculated in order to obtain and compare the energy balance of the systems evaluated in this paper (orange monoculture and agroforestry system).

For the monoculture of oranges the coefficient of reflection $r=0.16$ was adopted and for agroforestry $r=0.12$.

Considering a humid climate, the BOC and BOL were calculated according to the following equations: 


$$
\begin{aligned}
& B O C=Q g-r Q g=Q g(1-r) \\
& Q g=(0.29 \cos \Phi+0.52 n / N) * Q o
\end{aligned}
$$

Where: $\Phi:$ latitude, expressed in degrees and tenths; $\mathrm{n}$ : daily insolation; $\mathrm{N}$ : photoperiod, represents the maximum number of hours with solar brightness on the day.

Thus:

$$
\begin{aligned}
& B O C=(Q o(0.29 \cos \varphi+0.52 n / N)) *(1-r) \\
& B O L=-\left[4.90310^{-9} T_{A R}^{4}(0.56-0.25 \sqrt{e a})\right. \\
& (0.1+0.9 n / N)]\left(\mathrm{MJ} \mathrm{m}{ }^{-2} \mathrm{~d}^{-1}\right)
\end{aligned}
$$

When:

TAR : average daily air temperature in Kelvin = $273+\mathrm{T}$ in ${ }^{\circ} \mathrm{C}$

ea $=$ partial pressure of air vapor $(\mathrm{kPa})$ $\left[0.611^{\star} 10\left(7.5^{\star} \mathrm{T} /(237.3+\mathrm{T})\right]^{\star} \mathrm{UR} \% / 100\right.$

\section{UR: relative humidity}

In vegetated systems, the energy balance $(\mathrm{Rn})$ can be used to heat air and plants ( $\mathrm{H}$, sensitive heat), soil heating $(\mathrm{G})$, evapotranspiration (LE, latent heat), and biological synthesis processes $(\mathrm{F})$. Energy utilization in photosynthesis is less than $3 \%$ of Rn, so F becomes negligible (PEREIRA; ANGELOCCI; SENTELHAS, 2007).

Based on the results obtained by Machado et al. (2014), the energy balance for the systems under study was calculated considering the energy distribution for the processes according to the following equations:

For the orange monoculture:

$$
R n=0.2 H+0.1 G+0.7 L E
$$

For the agroforestry system:

$$
R n=0.075 H+0.075 G+0.85 L E
$$

\section{Results and discussion}

\subsection{Water Balance}

The $I$ and $a$ indices calculated were 108.36 and 2.39, respectively. Based on these values and the mean air temperature data, ETP was calculated for a condition without regard to agriculture, and for the orange monoculture and agroforestry systems.

The data on mean temperature, precipitation and ETP for a condition without considering agriculture are shown in Table 4.

The estimated values for ETP, without considering any crop, varied from $43.8 \mathrm{~mm}$ for the month of June to

\begin{tabular}{|c|c|c|c|}
\hline Weather & $\mathrm{T}$ & $P$ & ETP \\
\hline Month & ${ }^{\circ} \mathrm{C}$ & $\mathrm{mm}$ & $\mathrm{mm}$ \\
\hline J & 22.7 & 495.0 & 107.4 \\
\hline F & 23.8 & 150.6 & 105.9 \\
\hline M & 23.0 & 201.3 & 103.6 \\
\hline$A$ & 23.6 & 7.2 & 101.0 \\
\hline M & 18.9 & 149.7 & 58.2 \\
\hline$J$ & 17.3 & 98.8 & 43.8 \\
\hline$J$ & 19.3 & 2.6 & 58.5 \\
\hline A & 20.0 & 56.2 & 65.6 \\
\hline S & 20.8 & 31.8 & 73.4 \\
\hline $\mathrm{O}$ & 21.8 & 172.2 & 89.6 \\
\hline $\mathrm{N}$ & 21.8 & 228.6 & 91.1 \\
\hline D & 23.1 & 202.2 & 111.5 \\
\hline Totals & & 1796.2 & 1009.5 \\
\hline Means & 21.3 & & 84.1 \\
\hline
\end{tabular}
$111.5 \mathrm{~mm}$ for the month of December.

The previously calculated ETP data with those of ETc estimated for orange monoculture are shown in Table 5 .
Table 4 - Climatic data and estimation of ETP for the municipality of São Carlos, referring to the year 2016

Table 5 - ETP and ETc values for an orange monoculture, $\mathrm{Kc}=0.65$

\begin{tabular}{cccc}
\hline $\begin{array}{c}\text { Weather } \\
\text { Month }\end{array}$ & $\begin{array}{c}\mathrm{ETP} \\
\mathrm{mm}\end{array}$ & $\begin{array}{c}\mathrm{ETc} \\
\mathrm{mm}\end{array}$ & $\begin{array}{c}\mathrm{ETc} / \mathrm{m}^{2} \\
\mathrm{~mm}\end{array}$ \\
\hline $\mathrm{J}$ & 107.4 & 69.82 & 2.905 \\
$\mathrm{~F}$ & 105.9 & 68.81 & 2.863 \\
$\mathrm{M}$ & 103.6 & 67.36 & 2.802 \\
$\mathrm{~A}$ & 101.0 & 65.62 & 2.730 \\
$\mathrm{M}$ & 58.2 & 37.83 & 1.574 \\
$\mathrm{~J}$ & 43.8 & 28.49 & 1.185 \\
$\mathrm{~J}$ & 58.5 & 38.00 & 1.581 \\
$\mathrm{~A}$ & 65.6 & 42.63 & 1.773 \\
$\mathrm{~S}$ & 73.4 & 47.69 & 1.984 \\
$\mathrm{O}$ & 89.6 & 58.21 & 2.421 \\
$\mathrm{~N}$ & 91.1 & 59.19 & 2.462 \\
$\mathrm{D}$ & 111.5 & 72.48 & 3.015 \\
\hline Totals & 1009.5 & 656.1 & 27.3 \\
Means & 84.1 & 54.7 & 2.3 \\
\hline
\end{tabular}

ETc values for orange monoculture varied from 28.49 $\mathrm{mm}$ for the month of June to $72.48 \mathrm{~mm}$ for the month of December, with a total of $656.1 \mathrm{~mm}$. The column referring to ETc $\left(\mathrm{m}^{2}\right)$ considers the conditions of the crop in $1 \mathrm{sqm}$, so that later this data can be used for comparisons with the agroforestry system.

To obtain a common value of the three cultures adopted in the agroforestry system suggested in this paper, the ETc of each culture was first calculated. Considering the reduction in the microclimate caused by eucalyptus shading in the system ( $7 \%$ in relation to temperature), 
the average projected temperature to estimate ETP and ETc of banana and orange crops, as well as ETP and ETc values, are shown in Table 6.

Table 6 - Mean air temperature, ETP and ETc for the orange and banana crops in the agroforestry system, considering $\mathrm{Kc}=0.65$ and $\mathrm{Kc}=1.00$ respectively

\begin{tabular}{lcccc}
\hline Month & $\mathrm{T}$ & $\begin{array}{c}\text { ETP } \\
\mathrm{mm}\end{array}$ & $\begin{array}{c}\text { ETC } \\
\text { ORANGE } \\
\mathrm{mm}\end{array}$ & $\begin{array}{c}\text { ETc } \\
\text { BANANA } \\
\mathrm{mm}\end{array}$ \\
\hline $\mathrm{J}$ & 21.1 & 90.3 & 58.7 & 90.3 \\
$\mathrm{~F}$ & 22.1 & 89.0 & 57.9 & 89.0 \\
$\mathrm{M}$ & 21.4 & 87.1 & 56.6 & 87.1 \\
$\mathrm{~A}$ & 21.9 & 84.9 & 55.2 & 84.9 \\
$\mathrm{M}$ & 17.6 & 48.9 & 31.8 & 48.9 \\
$\mathrm{~J}$ & 16.1 & 36.9 & 23.9 & 36.9 \\
$\mathrm{~J}$ & 17.9 & 49.1 & 31.9 & 49.1 \\
$\mathrm{~A}$ & 18.6 & 55.1 & 35.8 & 55.1 \\
$\mathrm{~S}$ & 19.3 & 61.7 & 40.1 & 61.7 \\
$\mathrm{O}$ & 20.3 & 75.3 & 48.9 & 75.3 \\
$\mathrm{~N}$ & 20.3 & 76.6 & 49.8 & 76.6 \\
$\mathrm{D}$ & 21.5 & 93.8 & 60.9 & 93.8 \\
\hline TOTALS & & 848.7 & 551.7 & 848.7 \\
MEANS & 19.8 & 70.7 & 46.0 & 7.7 \\
\hline
\end{tabular}

The new ETP values for agroforestry, estimated based on the $7 \%$ reduction in temperature, ranged from 36.9 $\mathrm{mm}$ for the month of June to $93.8 \mathrm{~mm}$ for the month of December. The ETc values for orange and banana crops vary from $23.9 \mathrm{~mm}$ and $36.9 \mathrm{~mm}$ (June) to $60.94 \mathrm{~mm}$ and $93.8 \mathrm{~mm}$ (December), respectively.

The estimated ETc for eucalyptus is shown in Table 7.

Table 7 - Estimation of ETc for eucalyptus, considering $\mathrm{Kc}=1$

\begin{tabular}{cc}
\hline Month & $\begin{array}{c}\text { ETc EUCALYPTUS } \\
\text { Mm }\end{array}$ \\
\hline$J$ & 107.4 \\
F & 105.9 \\
M & 103.6 \\
A & 101.0 \\
M & 58.2 \\
$J$ & 43.8 \\
$J$ & 58.5 \\
A & 65.6 \\
S & 73.4 \\
O & 89.6 \\
N & 91.1 \\
D & 111.5 \\
\hline Totals & 1009.5 \\
\hline
\end{tabular}

The ETc values for the Eucalyptus crop of the agroforestry system varied from $43.8 \mathrm{~mm}$ for the month of June to $111.5 \mathrm{~mm}$ for the month of December. Subsequently, these data shown in Tables 6 and 7 (ETc by crop adopted) will be used together to calculate the sequential water balance of the agroforestry system.

Based on the estimated ETP and ETc values for the crops, the sequential water balance was calculated for a situation without agriculture, for the orange monoculture and for the agroforestry system. It is important to emphasize that in order to be able to consider the three crops in the agroforestry system, the calculated values in the water balance represent an area of $1 \mathrm{~m}^{2}$.

The estimated values of the sequential water balance for the year 2016, without considering agriculture as soil cover, are shown in Table 8 and in Figure 3.

Figure 3 - Water balance statement for the year 2016, $\mathrm{CAD}=100 \mathrm{~mm}$

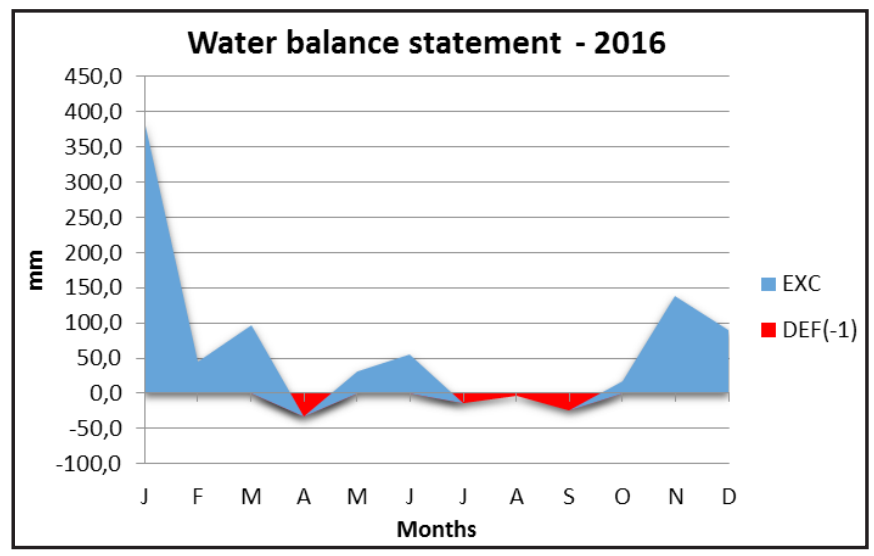

Based on the estimation of $\mathrm{BH}$, it can be seen that there were water deficits (DEF) for the months of April, July, August and September, with values of $32.9 \mathrm{~mm}, 13.1$ $\mathrm{mm}, 4.3 \mathrm{~mm}$ and $23,9 \mathrm{~mm}$, respectively, and a total of $74.1 \mathrm{~mm}$. The deficiency in these months is explained by the fact that the PREC in these months was lower than ETP, that is, the precipitation in the region was not enough to supply the water demand. On the other hand, the surplus (EXC) varied from 0 for the months with water deficiency to $387.6 \mathrm{~mm}$ for the month of January, with a total of $860.8 \mathrm{~mm}$.

Likewise, the estimated water balance for the orange monoculture was calculated at $1 \mathrm{~m}^{2}$, which can be seen in Figure 4.

No water deficit was observed, concluding that the PREC was sufficient to supply the crop's water demand. The EXC ranged from $1.0 \mathrm{~mm}$ for the month of July to $492.1 \mathrm{~mm}$ for the month of January, presenting a total of $1768.9 \mathrm{~mm}$.

Figure 5 presents the estimated water balance for the agroforestry system.

It was also observed that there was no water deficiency, however it can be said that the PREC was sufficient to supply the water demand of the agroforestry. The EXC varied from $0 \mathrm{~mm}$ for the month of April to $484.6 \mathrm{~mm}$ for the month of January, presenting a total of $1698.4 \mathrm{~mm}$. 
Table 8 - Sequential Water Balance, year 2016, CAD = 100 mm, Latitude: -21.96

\begin{tabular}{lccccccc}
\hline $\begin{array}{c}\text { Weather } \\
\text { Month }\end{array}$ & $\begin{array}{c}\text { P-ETP } \\
\mathrm{mm}\end{array}$ & NEG-AC & $\begin{array}{c}\text { ARM } \\
\mathrm{mm}\end{array}$ & $\begin{array}{c}\text { ALT } \\
\mathrm{Mm}\end{array}$ & $\begin{array}{c}\text { ETR } \\
\mathrm{mm}\end{array}$ & $\begin{array}{c}\text { DEF } \\
\mathrm{mm}\end{array}$ & $\begin{array}{c}\text { EXC } \\
\mathrm{mm}\end{array}$ \\
\hline $\mathrm{J}$ & 387.6 & 0.0 & 100.0 & 0.0 & 107.4 & 0.0 & 387.6 \\
$\mathrm{~F}$ & 44.7 & 0.0 & 100.0 & 0.0 & 105.9 & 0.0 & 44.7 \\
$\mathrm{M}$ & 97.7 & 0.0 & 100.0 & 0.0 & 103.6 & 0.0 & 97.7 \\
$\mathrm{~A}$ & -93.8 & -93.8 & 39.2 & -60.8 & 68.0 & 32.9 & 0.0 \\
$\mathrm{M}$ & 91.5 & 0.0 & 100.0 & 60.8 & 58.2 & 0.0 & 30.6 \\
$\mathrm{~J}$ & 55.0 & 0.0 & 100.0 & 0.0 & 43.8 & 0.0 & 55.0 \\
$\mathrm{~J}$ & -55.9 & -55.9 & 57.2 & -42.8 & 45.4 & 13.1 & 0.0 \\
$\mathrm{~A}$ & -9.4 & -65.2 & 52.1 & -5.1 & 61.3 & 4.3 & 0.0 \\
$\mathrm{~S}$ & -41.6 & -106.8 & 34.4 & -17.7 & 49.5 & 23.9 & 0.0 \\
O & 82.6 & 0.0 & 100.0 & 65.6 & 89.6 & 0.0 & 17.0 \\
$\mathrm{~N}$ & 137.5 & 0.0 & 100.0 & 0.0 & 91.1 & 0.0 & 137.5 \\
$\mathrm{D}$ & 90.7 & 0.0 & 100.0 & 0.0 & 111.5 & 0.0 & 90.7 \\
\hline Totals & 786.7 & & & 0.0 & 935.4 & 74.1 & 860.8 \\
Means & 65.6 & & & 0.0 & 77.9 & 6.2 & 71.7 \\
\hline
\end{tabular}

Figure 4 - Sequential Water Balance statement for an orange monoculture, for the year 2016, CAD $=100 \mathrm{~mm}$

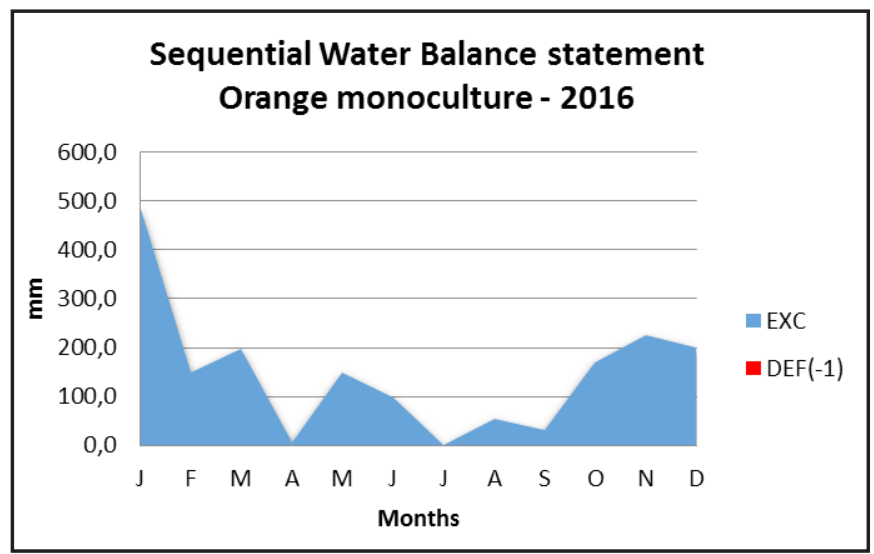

Narain et al. (1998) observed that in mixtures of tree crops there is a more efficient use of water in the soil compared to monoculture systems. According to the authors, the results indicate that the water conserved due to the intervention of trees using agroforestry through reduction of flow, is used to meet the demand for increased evapotranspiration.

However, in this study, when comparing the water balance estimates, there was no increase in the EXC for the agroforestry system as expected. This finding can be explained by the fact that, even with the $7 \%$ reduction in microclimate temperature (which influences crop evapotranspiration - ETc), the PREC was enough to supply the water demand of the crops analyzed in the two systems analyzed.
Figure 5 - Sequential Water Balance statement for agroforestry, for the year 2016, CAD $=150 \mathrm{~mm}$

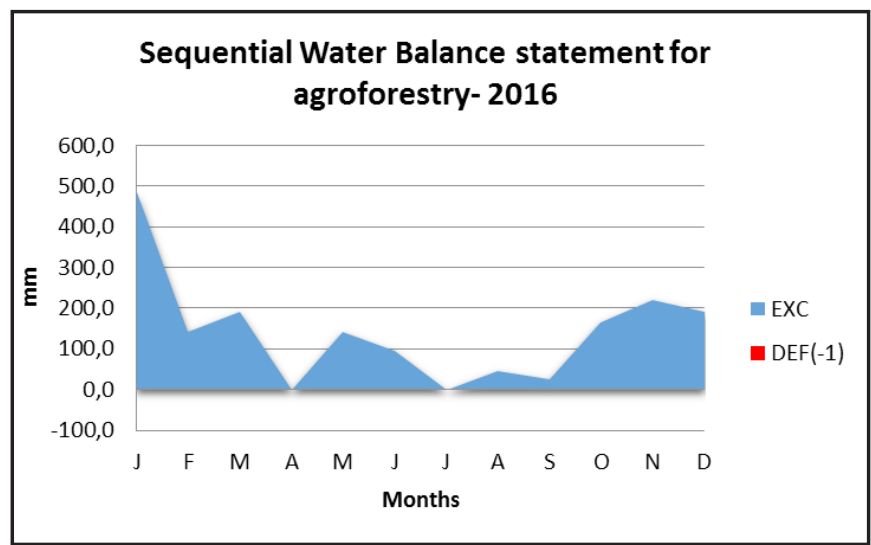

Luedeling et al. (2016) emphasize that the proportion of documented or aggregate benefits of agroforestry systems depends on site-specific responses by trees, crops or other system components, with great variation between geographic locations and agricultural contexts. In addition, the authors point out that benefits also vary over time, because many effects of trees on soil are slow processes to consolidate.

Thus, it should be emphasized that other factors should be considered in a comparative analysis of the agricultural systems. Therefore, it is recommended that field studies such as soil moisture measurements, Kc relationship with spacing, among others, be carried out in order to evaluate the water behavior and the possible increase of the amount of available water, in the agroforestry system. 


\subsection{Energy balance}

The radiation balance $(\mathrm{Rn})$ was estimated for the orange monoculture system and for the agroforestry system, in order to compare the energy balance in the two agricultural systems.

The daily data of Rn for the orange monoculture system are shown per quarter, 1st quarter (January to March), 2nd quarter (April to June), 3rd quarter (July to September) and 4th quarter (October to December) (Figure 6).

Figure 6 - Estimation of the radiation balance (Rn) for orange monoculture for the year 2016

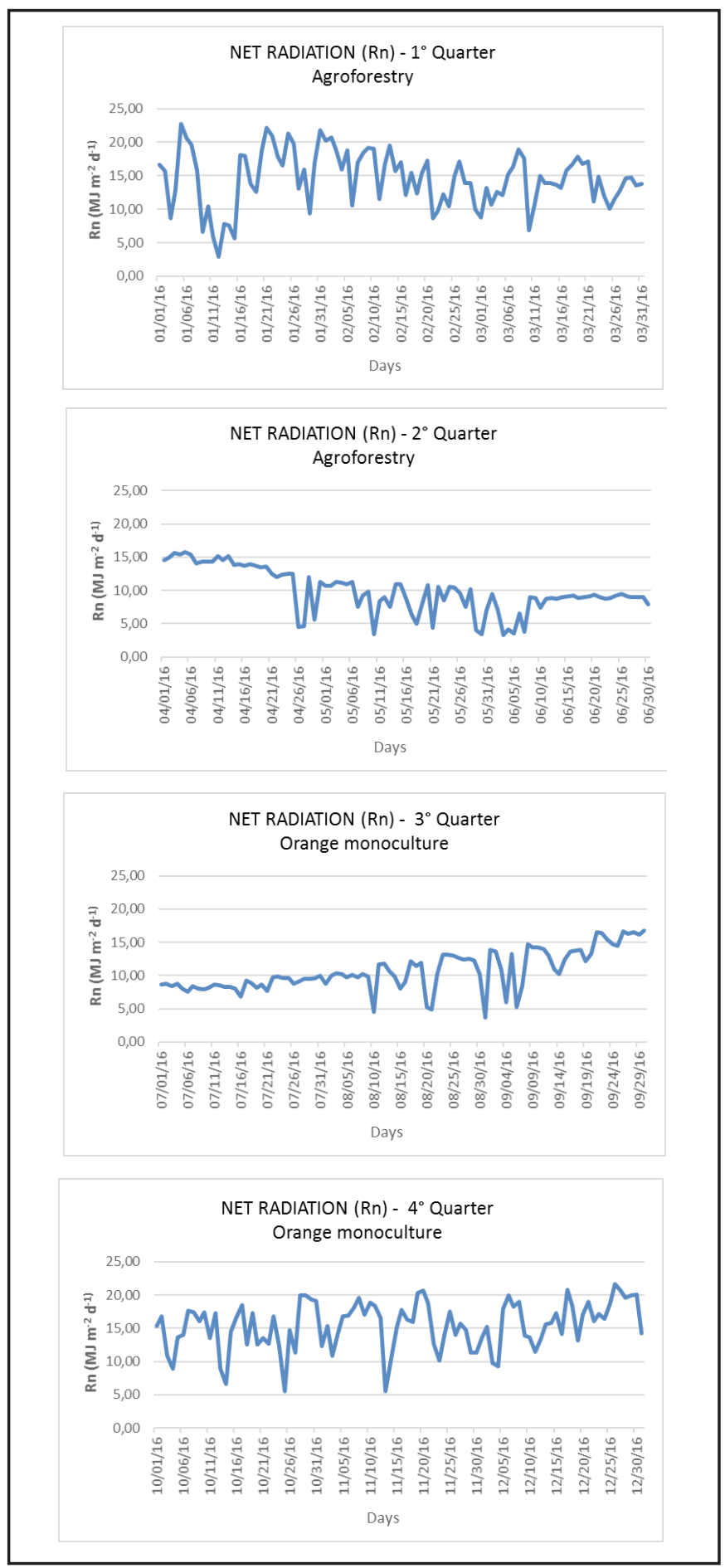

In the 1st quarter, the daily values of Rn for orange monoculture varied from 2.82 to 21.55 , for the 2 nd quarter from 3.19 to 14.85 , for the $3 r$ q quarter from 3.70 to 16,74 and for the fourth quarter from 5.54 to 21.66 .

Based on the average values of $\mathrm{Rn}$ for each quarter, the energy balance was calculated, when the fraction of the energy used for each biophysical process in the monoculture system was obtained. The results are shown in Table 9.

Table 9 - Energy balance for orange monoculture for the year 2016

\begin{tabular}{ccccc}
\hline & $\mathrm{Rn}$ & $\mathrm{H}$ & $\mathrm{G}$ & $\mathrm{LE}$ \\
\hline $1^{\circ}$ QUARTER & 13.79 & 2.76 & 1.38 & 9.65 \\
$2^{\circ}$ QUARTER & 9.28 & 1.86 & 0.93 & 6.49 \\
$3^{\circ}$ QUARTER & 10.70 & 2.14 & 1.07 & 7.49 \\
$4^{\circ}$ QUARTER & 13.79 & 2.76 & 1.38 & 9.65 \\
\hline
\end{tabular}

As shown in the methodology of this work, the energy balance $(\mathrm{Rn})$ shown here is divided into energy fractions for: air and plant heating $(\mathrm{H}$, sensitive heat), soil heating (G) and evapotranspiration (LE, latent heat).

The daily $\mathrm{Rn}$ data for the agroforestry system are shown in figure 7 also divided into quarters.

The values of $\mathrm{Rn}$ for agroforestry varied for the $1 \mathrm{st}$ quarter from 2.90 to 22.77 , for the 2 nd quarter from 3.32 to 15.74 , for the 3rd quarter from 3.84 to 17.78 and for the fourth quarter from 5.79 to 22.90

As for the orange monoculture, from the average values of $\mathrm{Rn}$ for each quarter, the energy balance for agroforestry was calculated. The results are shown in table 10 .

In order to perform a comparative analysis between the results of the energy balance for the two systems adopted (orange monoculture and agroforestry system ), the graph in Figure 8 was constructed, presenting the values of the energy balance $(\mathrm{Rn})$ for each quarter of the year 2016, considering each system.

Analyzing the graph, it can be seen that, although the difference is small, in general the agroforestry system presented higher energy balance $(\mathrm{Rn})$ than the conventional orange monoculture system, the biggest difference being found in the fourth quarter of the year. Thus, the agroforestry system enables a greater balance of energy available for the system's physical and biological processes.

It should be noted that integrating trees with other crops also adds the element of biological diversity to agronomic systems, a factor that, although not quantified in the paper, must be considered since it promotes sustainable, protective and productive use of land. Jianbo (2006) concluded that consortium in agroforestry systems can increase energy flow, especially when the input of biological energy is added. The benefits to farmers of these systems are significant and there are also significant ecological benefits.

Energy efficiency and the economic benefits of agroforestry systems are key issues with regard to real sustainability as sound agricultural practices as well as their potential for further development (JIANBO, 2006). 
Figure 7 - Estimation of the radiation balance $(\mathrm{Rn})$ for agroforestry, for the year 2016

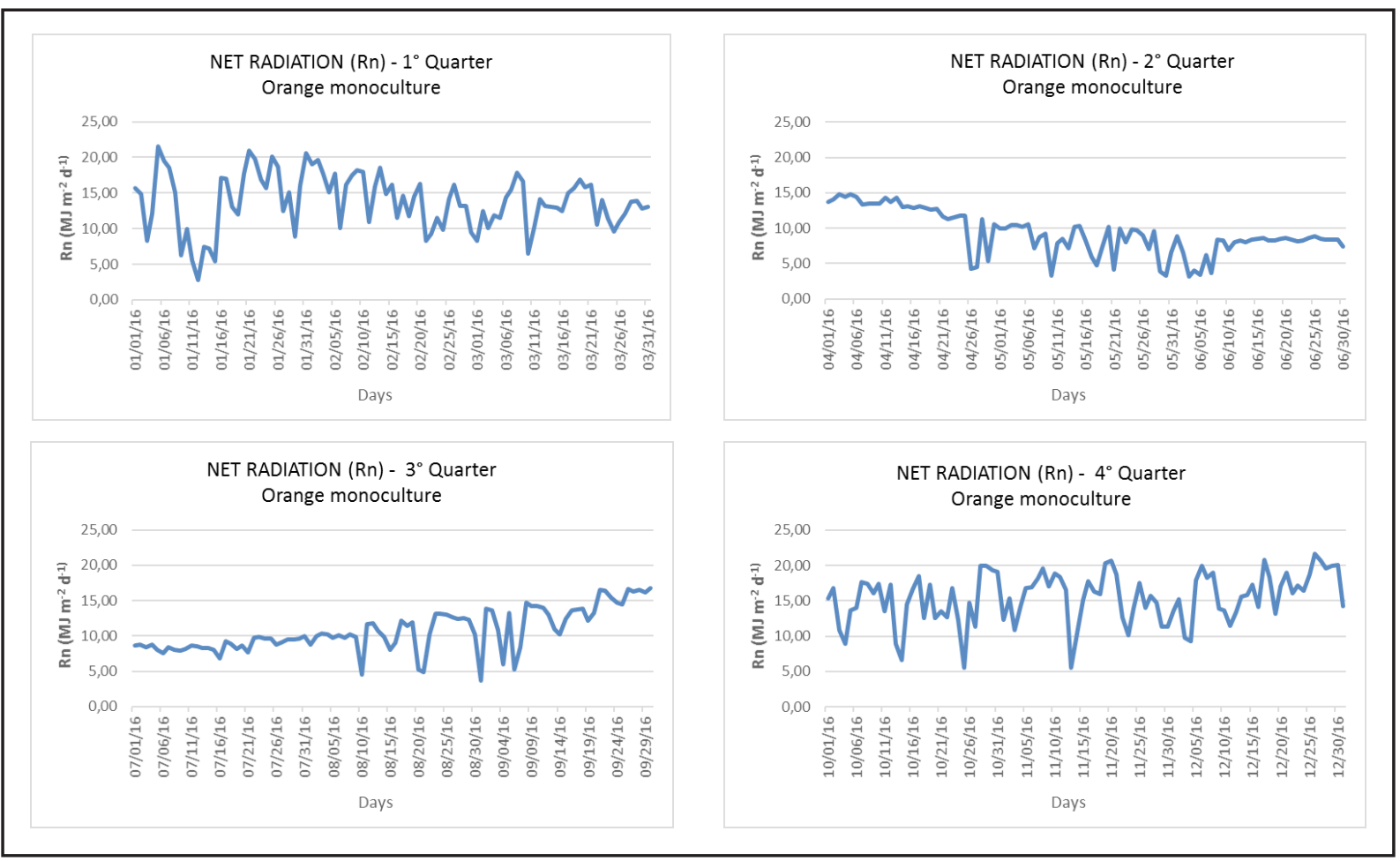

Figure 8 - Comparative chart of the monoculture orange energy balance and the agroforestry system, by quarter of 2016

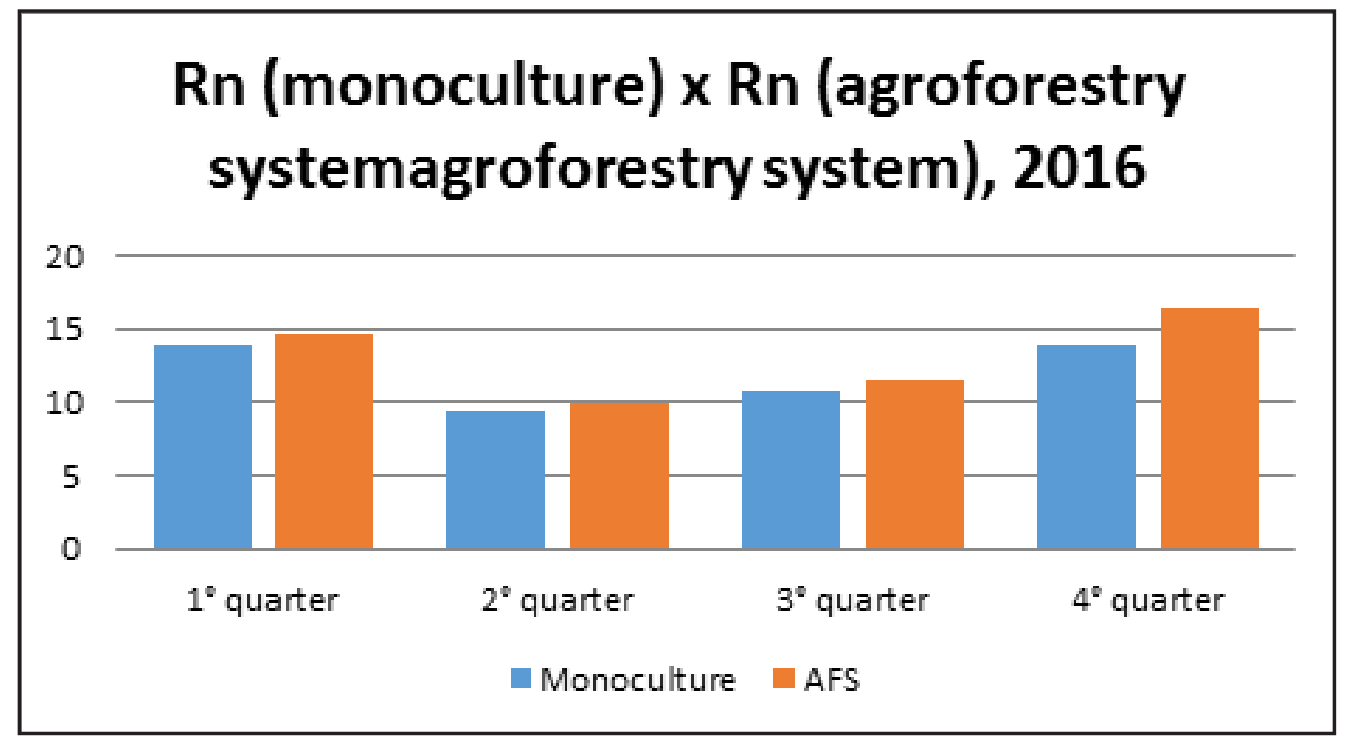

Figure 8 - Comparative chart of the monoculture orange energy balance and the agroforestry system, by quarter of 2016

\begin{tabular}{lcccc}
\hline & $\mathrm{Rn}$ & $\mathrm{H}$ & $\mathrm{G}$ & $\mathrm{LE}$ \\
\hline $1^{\circ}$ QUARTER & 14.55 & 1.09 & 1.09 & 12.37 \\
$2^{\circ}$ QUARTER & 9.90 & 0.74 & 0.74 & 8.42 \\
$3^{\circ}$ QUARTER & 11.43 & 0.86 & 0.86 & 9.71 \\
$4^{\circ}$ QUARTER & 16.31 & 1.22 & 1.22 & 13.86 \\
\hline
\end{tabular}

\section{Conclusions}

The conventional farming system currently used, due to its focus on quantity to the detriment of quality of the processes and products generated, ends up having a range of negative impacts, particularly on soil and water. These agricultural impacts can be minimized or extinguished through the use of more ecologically stable and resilient agroecosystems with fewer external inputs and greater self-sufficiency, such as agroforestry systems.

These systems enable, among many factors, improvements to soil and microclimate fertility, greater conservation of water and energy resources, maintenance of 
water quality, biodiversity conservation, carbon sequestration and greenhouse gas mitigation and promoting food security for small farmers.

In relation to this greater conservation of water and energy resources, in this paper it was possible to partially confirm this observation. Although the comparison between orange monoculture and agroforestry system water balances including eucalyptus, orange and banana did not generate an increase in the water surplus in the agroforestry, the energy balance of the systems resulted in a greater balance of available energy in the synoptic system, confirming that it helps to conserve these resources.

It is also worth noting that in these analyses of energy balances and, especially, water balance, other factors should be considered in a comparative analysis with other agricultural systems, therefore, it is recommended that field studies such as soil moisture measurements, Kc with crop spacing, among others, be carried out in order to evaluate water behavior and the possible increase of the amount of water in the agroforestry system.

The discussions presented and the results obtained in this work will help in the decision making regarding the adequate and sustainable management of agricultural systems and collaborate with management and conservation of natural resources.

\section{Acknowledgements}

To Coordination for Improvement of Higher Education Personnel (CAPES), and to National Council for Scientific and Technological Development (CNPq)

\section{References}

ARMANDO, M. S.; BUENO, Y. M.; ALVES, E. R. da S.; CAVAlCANTE, C. H. Agrofloresta para Agricultura Familiar. In: Embrapa Recursos Genéticos e Biotecnologia. Circular Técnica. Brasilia: Editora EMBRAPA, 2002. v. 1,11p.

CENTRO DE PESQUISAS METEOROLÓGICAS E CLIMÁTICAS APLICADAS A AGRICULTURA CEPAGRI. Available from: http://www.cpa.unicamp.br.

CERMINARO, A. C. Caracterização macro e micromorfológica do solo para compreensão de processos erosivos lineares, topossequência Manacá, São Carlos - SP (dissertation). São Paulo - SP: Universidade de São Paulo; 2016, 136p.

CERMinARO, A. C.; OLIVEIRA, D. DE. As Relações SoloRelevo Através da Compartimentação Geomorfológica da Bacia Hidrográfica do Ribeirão Feijão, nos Municípios de São Carlos, Analândia e Itirapina no Estado de São Paulo-BR: Ordenações de Unidades para Uso e Ocupação Adequados. Revista Brasileira de Geografia Física, v. 8, n. 2, p. 352-364, 2015.
CUNHA, R. C. da. Análise da influência das variáveis ambientais na determinação das vulnerabilidades ambientais da Bacia Hidrográfica do Ribeirão do Feijão, São Carlos, SP (dissertation). Itajubá - MG: Universidade Federal de Itajubá; 2012, 99p.

ENGEL, V. L. Introdução aos Sistemas Agroflorestais. Botucatu: FEPAF, 1999.

JIANBO, L. Energy balance and economic benefits of two agroforestry systems in northern and southern China. Agriculture, Ecosystems and Environment, v. 116, p. 255-262, 2006.

KARVATTE JUNIOR, N. K. Microclima em sistemas de integração e características quanti-qualitativas da sombra de espécies arbóreas nativas e cultivada, no cerrado (dissertation). Universidade Estadual do Oeste do Paraná - Marechal Cândido Rondon -PR; 2014; 81 p.

KARVATTE JUNIOR, N.; ALVES, F.; KLOSOWSKI, E.; de AlmeidA, R. G.; TSUTSUMI, C.; OLIVEIRA, C. Microclima e índices de conforto térmico em sistemas de integração lavoura-pecuária-floresta no município de Campo Grande, Mato Grosso do Sul. Documentos (INFOTECA-E), 2016. Available from: <https://www. infoteca.cnptia.embrapa.br/infoteca/handle/doc/1056742>.

KOHLI, R. K.; SINGH, H. P.; BATISH, D. R.; JOSE, S. Ecological interactions in Agroforestry: An overview. In: BATISH, D. R.; KOHLI, R. K.; JOSE, S.; SINGH, H. Ecological basis of Agroforestry. Boca Raton: CRC Press, 2008.

INSTITUTO BRASILEIRO DE GEOGRAFIA E ESTATÍSTICA - IBGE. Available at: http://cod.ibge. gov.br/3DW.

LU, S.; WANG, F.; MENG, P.; ZHANG, J. Simultaneously protecting the environment and its residents: The need to incorporate agroforestry principles into the ecological projects of China. Ecological Indicators, v. 57, p. 61-63, 2015.

LUEDELING, E. et al. Field-scale modeling of treecrop interactions: Challenges and development needs. Agricultural Systems, v. 142, p. 51-69, 2016.

MACHADO, F. H.; MATTEDI, A. P.; DUPAS, F. A.; SILVA, L. F.; VERGARA, F. E. Estimating the opportunity costs of environmental conservation in the Feijão River watershed (São Carlos-SP, Brazil). Brazilian Journal of Biology, v. 76, p. 28-35, 2016.

MACHADO, C. C.; DA SILVA, B. B.; DE ALBUQUERQUE, M. B.; GALVÍNCIO, J. D Estimativa do balanço de energia utilizando imagens TM - Landsat 5 e o algoritmo SEBAL no litoral sul de Pernambuco. Revista Brasileira de Meteorologia, v. 29, n. 1, p. 55-67, 2014. 
MONTEITH, J.L.; ONG, C.K.; CORLETT, J.E. Microclimatic interactions in agroforestry systems. Forest Ecology and Management, Amsterdam, v. 45, p. 31-44, 1991.

NAIR, P.K.R. Agroforestry systems in the tropics. London: Kluwer, 1989. 664p.

NARAIN, P.; SINGH, R. K.; SINDHWAL, N. S.; JOSHIE, P. Water balance and water use efficiency of different land uses in western Himalayan valley region. Agricultural Water Management, v. 37, p. 225-240, 1998.

NARDELE, M.; CONDE, I. Apostila de Sistemas Agroflorestais. In: Projeto Curso de Formação de Agentes de Reflorestamento. Rio de Janeiro: UFRRJ, 2008.

NISHIYAMA, L. Mapeamento Geotécnico Preliminar da Quadrícula de São Carlos - SP. São Carlos - SP: Universidade de São Paulo, 1991.

PEREIRA, A. R.; ANGELOCCI, L. R.; SENTELHAS, P. C. Meteorologia Agrícola. Edição Revista e Ampliada. Piracicaba: Escola Superior de Agricultura "Luiz de Queiroz” - USP, Piracicaba, 2007.125 p.

REICHERT, J. M.; SUZUKI, L. E. A. S.; REINERT, D. J. Compactação do solo em sistemas agropecuários e florestais: identificação, efeitos, limites críticos e mitigação. Tópicos de Ciências do Solo, v.5, p. 49-134, 2007.

SÁ, M. A. C. de; SHIRATSUCHI, L. S.; FRANZ, C. A. B.; SANTOS JÚNIOR, J. de D. G. dos. Compactação do Solo e Produtividade da Cultura de Soja. Planaltina: Embrapa Cerrados, 2007.

SINGH, A.K.; KUMAR, P.; SINGH, R.; RATHORE, N. Dynamics of tree-crop interface in relation to their influence on microclimatic changes: a review. HortFlora Research Spectrum, Meerut, v.1, n. 3, p.193-198, 2012.

THORNTHWAITE, C. W. An approach toward a rational classification of climate. Geographical review, v.38, p. 55-94, 1948.

THORNTHWAITE, C. W.; MATHER, J. R. The water balance. Publications in climatology, New Jersey: Drexel Institute of technology, 1955, 104p.

YOUNG, A. Agroforestry in the control of soil erosion by water. Agroforestry Abstracts. London, v.1, n.2/3, p.39-48, 1988. 